\title{
Economic and Political Initiatives of European Integration for the Period 1945-1992
}

\section{W Viviers}

Department of Economics, Potchefstroom University for CHE

T F J Steyn

Department of Business Management, Potchefstroom University for CHE

\begin{abstract}
The integration of the European Communities (EC, today EU) has been described as one of the most successful examples of economic integration worldwide. This study examines the reason for this success from two perspectives. Firstly, the economic success of EC integration for the period 1945 to 1992 is investigated. It is concluded that, notwithstanding difficulties experienced, the economic integration process represents the EC's greatest achievement. An example of this is the completion of the EC internal market through the European Economic Community (EEC) customs union and the EC-92 programme. Secondly, the investigation focuses on the political success of EC integration. The evaluation shows that political powerplay endangered and inhibited the process of economic integration in the $\mathrm{EC}$.
\end{abstract}

\section{INTRODUCTION}

Much has been written on economic and political integration in general, and on $\mathrm{EC} / \mathrm{EU}$ integration in particular. Different aspects and stages of EC integration have been placed under the spotlight. This study attempts to highlight a wider angle with the focus on mainly two aspects. The first aspect refers to the launching of successful and unsuccessful integration initiatives. The second aspect is to ascertain why some initiatives were successful, and others not. The study will seek 
to answer these questions by comparing economic reasons for EC integration with political ones. The relative successes and failures will also be highlighted.

However, to put the analysis into context, the concept of economic integration and the EC as an example thereof, will firstly be defined. Thereafter the rationale for Western European integration following the Second World War will be discussed. This will set the scene for an inquiry into the economic and political merits of EC integration.

\section{DEFINITION OF ECONOMIC INTEGRATION}

Balassa (1961:1) viewed economic integration inter alia as a process. This process comprises both a "negative" and a "positive" integration stage. "Negative" integration implies the removal of existing trade barriers between countries (Tinbergen, 1954:122), while "positive" integration means the establishment and co-ordination of regulatory frameworks and economic measures into a common policy (Mayer, 1990:79). These two stages have the combined effect of drawing national economies closer together.

Against this background, five different forms of economic integration may be distinguished. These include a free trade area, customs union, common market, an economic union and a monetary union (Matthews, 1987:60-61). In general these forms involve varying degrees of complexity. Free trade areas focus only on "negative" integration, as tariffs and quotas between countries are eliminated. A customs union adds a common external tariff on imports from nonmembers to the free trade area characteristics. In addition, a common market provides for the free movement of goods and factors of production between members states. Together with the above, an economic union also facilitates common policy formulation in certain fields of economic activity (Matthews, 1987:61). A monetary union extends the concept of an economic union to common policy formulation in all fields of economic activity, as well as the use of the same curtency by all member countries. Where the same currency is not used, the respective currencies are totally and irreversibly convertible, while their exchange rates are irrevocably fixed to each other. In addition, capital movements are completely free in fully integrated financial markets (Anon, 1993:209, 219). 


\section{THE EC AS AN EXAMPLE OF ECONOMIC INTEGRATION}

The EEC Treaty of 1957 provided for the creation of a customs union among its six signatories. In July 1968 all tariffs between the six EEC members were abolished and a common external tariff came into operation (European Communities, 1971:32). This completed the customs union stage.

In terms of Article 2 of the EEC Treary the customs union was to develop into at least a common market, and preferably into an economic union (Vaughan, 1976:75). Due to EC policy development in reaction to the economic circumstances at the time, the realisation of the common market ideal was somewhat lost during the 1970s and early 1980s (Robinson, 1992:68). The EC-92 initiative (on completion of the internal market) was therefore required to put new life into the effort.

Overtures towards an EC economic union were made in due course. Eventually an even closer integrated EC was proposed with the signing of the Treaty on European Union, or Maastricht Treaty. In terms of this treaty the European Union (EU) now strives towards closer economic, monetary, military and political integration (Hunnings \& Hill, 1993:725-726).

It is therefore evident that the EC started out as a customs union (one of the simplest forms of integration), and is at present developing into at least a monetary union (one of the more complex forms of integration). Further prospects of development towards a European (political) union are also raised.

To speculate on the possible success of such an endeavour, three issues must be considered, namely, the rationale for European economic integration, the success of the economic motivation the EC integration, and the success of the political motivation for EC integration.

\section{TWO-TIER RATIONALE FOR ECONOMIC INTEGRATION}

Contemporary integration efforts in Western Europe after the Second World War were mainly motivated on political and economic grounds.

The political motive is evident from Winston Churchill's post-war call for Franco-German reconciliation in "a kind of United States of Europe" (Walsh \& Paxton, 1972:14). By this he once again voiced the idea of the pan-European movement originating in Napoleonic times about economic co-operation throughout Europe. Moreover Europe rapidly divided into distinct ideological 
blocs after the Second World War (Van de Meerssche, 1971:71). Interest in economic co-operation was therefore also designed to counteract the spread of Communism (Swanepoel, 1959:5).

The economic motive for integration originated in the need to rebuild the Western European economies after the war (Ligthelm, 1963:41). Europe, as a result of its damaged national economies, had lost its competitive position in world trade (Swanepoel, 1959:5). By breaking down intra-European economic barriers. economies of scale were realised in agriculture and industry. Economic integration was therefore seen as the means of restoring economic prosperity to the region, as well as purting an end to possible future conflict and fragmentation between European nations (European Communities, 1971:3).

Given the political and economic motives for EC integration, various efforts were initiated in this direction. These efforts are analysed and evaluated below.

\section{ECONOMIC SUCCESS}

Efforts at realizing the post-Second World War political and economic objectives mainly resulted in the formation of the European Coal and Steel Community (ECSC) in 1951 and the European Economic Community (EEC) and European Atomic Energy Community (Euratom) in 1957 (European Communities, 1971:3).

\section{The ECSC}

After a variety of integration initiarives that were launched after the Marshall Plan of 1947, the ECSC was formed by Belgium, France, Italy, Luxembourg, the Netherlands and West Germany (European Communication, 1971, p.3). ECSC aims included conomic growth, expanded employment and a higher stabdard of living in its member states, by integrating coal and steel production and consumption.

The ECSC Treaty provided for a stable supply of coal and steel, and their derivatives to the Community market (Vaughan, 1976:62). This was to be accomplished by facilitating equal access to production sources in the Community, establishing a framework to secure the lowest possible prices for products controlled within the Community, setting conditions to encourage enterprises expand production with a commitment to exploit national resources optimally, In addition, guidelines were set to promote general growth of international trade and 
suitable export prices, modemisation and expansion of production capabilities, improvement in the quality of products and better working conditions and standards of living for workers in the industries falling under the Community.

All of these objectives, save the last one, relate to economic conditions. The ECSC can therefore be seen as an initiative towards Westem European economic integration. The establishment of improved working conditions and standards of living, however, represented a social dimension of the ECSC.

The ECSC initiative was significant on three accounts. Firstly, ECSC integration minimised the possibility of future war between former Western European adversaries (Wegs, 1984:147). Secondly, through an experiment of sectoral economic integration, the ECSC provided the first realistic method of progressively integrating Western Europe. By providing for a common import tariff on coal and steel to be phased in over a five year period, visions were created for a future integration effort (Ligthelm, 1963:44). Lastly, the ECSC prepared Europeans to "think European". With the free movement of labour in integrated industries, social side-effects like for example the provision of housing and social security, moved into the supra-national sphere (Lane, 1985:226). This promoted progress in future integration efforts.

It follows therefore that the ECSC as an economic initiative of Western European integration did not exist in a vacuum. It necessarily introduced social side-effects as well as political and military realities.

\section{The EEC}

The EEC and Euratom treaties of 1957 were concluded between the same countries as the ECSC Treaty. The EEC Treaty aimed at creating a common market between the signatories, as well as the progressive approximation of their respective economic policies (Vaughan, 1976:75).

To succeed, a range of prospects were set up. These included the elimination of customs duties and quantitative trade restrictions, as well as all other restrictions with the effect of impeding trade between members, and the removal of obstacles to the free movement of products, persons, services and capital among members. Provision was made for measures to co-ordinate national policies, and to align national laws of member countries in order to facilitate proper functioning of the common market. Calls were made for the establishment of a common customs tariff, commercial policy towards non-members, agricultural policy and transport policy. Procedures to ensure fair competition in the common market, and 
to correct any imbalance of payments were created. The European Social Fund and European Investment Bank were established to promote the standard of living of workers, to improve employment opportunities in the Community and to allow for economic expansion. Lastly, the economic and social development of overseas countries (former colonies) and member territories was encouraged.

These prospects mainly focused on aspects of economic integration. However, the co-ordination of national policies, the creation of the Social Fund and the facilitation of economic and social development of colonies and territories added a supra-national dimension to the proposed common market. The Social Fund also conferred a social dimension on the EEC while the responsibility towards the economic and social development of former colonies provided a framework for a common foreign policy. With these development the EC surely moved into the ambit of an economic union.

The initial success of the EEC can be illustrated by the economic performance of its members from 1958 to 1962 . Industrial output in France rose by 30 percent, and in West-Germany by 39 percent. In the Netherlands the figure amounted to 44 percent, and in Italy to 73 percent. By 1962 trade among EEC members picked up by 130 percent on the 1958 level and the gross domestic product (GDP) of the EEC also increased by 25 percent for the four year period (Smith, 1985:448). The Netherlands and West Germany suffered because of a shortage of labour. However, due to the mobility of labour caused by the Community, migratory workers were able to alleviate this problem, while simultaneously reducing the level of unemployment in the south, e.g. Italy (Smith, 1985:448).

\section{Euratom}

The Euratom Treaty provided for the co-ordination, augmentation and qualified control of nuclear policies in prescribed fields of members' nuclear activities. These prescribed fields of activity included nuclear research, nuclear industrial activities, nuclear security control and international atomic affairs (Polach, 1964:71-72).

Euratom progressed well. When by 1969 the draft 1970 to 1974 Euratom programme was submitted, it contained a request to authorize the extension of its activities to non-nuclear scientific research. The request was granted, and Euratom was allowed to conduct nuclear research under contract and to undertake projects in conjunction with non-EC European states (European Communities, 1971:3132). 


\section{Economic difficulties of the 1970s and early 1980s}

It is therefore evident that initial economic integration as represented by the ECSC, EEC and Euratom had succeeded. Difficulties were, however, encountered during the 1970 s and early 1980 s. The EC economic decline during this period can be largely attributed to EC reaction to the economic circumstances of the era.

These circumstances are related to a variety of events. The failed Bretton Woods system of fixed exchange rates led to monetary instability and a negative influence on world trade, let alone the EC (Matthews, 1987:47).

The oil shocks of 1973 and 1979 created inflationary pressure as well as deficits in EC balances of payments (Seers, 1982:5). The detrimental effect was compounded by the fact that by 1973 imported oil represented 64 percent of EC energy consumption (Kerr, 1977:122).

Traditional EC shipbuilding, steel, textile and clothing industries were increasingly exposed to competition from Japan and the newly industrialized countries (Seers, 1982:5). Local EC markets in new industries like electronics, were dominated by multi-national organizations from Japan and the US, as EC productivity improvements decreased. This depressed EC producers' market share in the industries concerned. In addition, demand for EC products decreased as import-substituting industrialisation increased in the developing world (Seers, 1982:5).

EC unemployment increased from 2,9 percent in 1975 to 10,7 percent in 1986 as a result of deflationary measures taken to counteract inflation (Goodman, 1992:101). The EC economy was also over-regulated to protect it from extra-EC competition. Integration in fields such as the environment, foreign, regional and social policy were widened (Steyn, 1994:84-123).

EC economic performance by the mid-1980s was therefore disappointing. The use of non-tariff barriers (over-regulation) resulted in the fragmentation of the EC internal market and the forfeiting of benefits from economies of scale. The most efficient procedures were prevented from being implemented, instability in currency markets inhibited intra-EC trade and specialization, technological progress, levels of investment and ultimately, economic growth, lagged behind (Featherstone, 1990:3). EC economic performance fell behind in GDP growth and productivity to that of the USA and especially Japan (Goodman, 1992:95101). EC unemployment levels also exceeded those of the USA and Japan. A case of "Eurosclerosis" "was therefore diagnosed with the EC. 
The most important measure taken to rectify this situation was the formulation of the EC-92 programme in completion of the EC common market.

\section{EC-92 and the Maastricht Treaty}

The EC-92 programme was designed to complete the common market envisaged by the EEC Treaty of 1957 , thereby relaunching the Communities after the economic malaise of the 1970 s and early 1980 s.

The EC-92 programme was an effort to remove non-tariff trade barriers (i.e. physical, technical and fiscal) between EC members, in order to integrate the individual markets of member states into a growing and expanding single market of 320 million people. In addition, the expanding market was to be facilitated by ensuring the free movement of goods, labour, services and capital within the area of greatest economic advantage (Commission of European Communities, 1985:4$5)$.

The Maastricht Treaty was inter alia designed to carry forward the vision of the EEC Treaty by progressively approximating the economic policies of EC members. Two of its basic principles were to secure EC economic and monetary union and to aspire towards EC economic cohesion (Anon, 1992:8-13).

\section{Evaluation}

It is therefore clear that, norwithstanding the difficulties experienced, economic integration represents the EC's greatest success. Economic integration carried Western Europe from its post-Second World War position of destruction and despair to one of the three main hubs of global economic development and trade.

This fact can be illustrated by comparing population and GDP statistics. By 1990 the EC countries represented 6,2 percent of the global population, but produced 26,96 percent of global output. The world GDP per capita income was $\$ 4221$, while for the EC it was $\$ 18369$ (Anon, 1994:3).

\section{POLITICAL SUCCESS?}

One of the motives for EC integration was political. As integration involves a political will to effectuate successful co-operation between countries, politics has, 
through the years, played an important role in EC integration. This can be illustrated by evaluating political initiatives aimed at enhancing economic integration.

\section{The Council of Europe}

In May 1948 the Council of Europe was created with the idea of establishing formal measures for political and economic integration in Western Europe (Van de Meersche, 1971:103-105).

Continental members were of the opinion that a European federation with supra-national institutions governing and administrating Europe, was the way to structure the Council's activities. The UK held a contrary point of view, namely that because of her special relationship with the Commonwealth and the USA, she was not able to cede any sovereignty to supra-national European instinutions (Van de Meerssche, 1971:107-114).

A compromise decision accommodared both points of view. The Council consisted of two bodies, namely a Committee of Ministers comprising the foreign ministers of member countries (the British viewpoint), and a Consultative Assembly of Representatives or European Assembly constituted from members of parliament of member states (the Continental viewpoint) (Walsh \& Paxton, 1972:8).

As Scandinavian members of the Council supported the UK's vision of European co-operation rather than political integration in a federation, the Council only discussed European political integration, but was not able to take any concrete steps in that direction. This political initiative therefore did not contribute towards meaningful Western European integration.

\section{The European Defence Community and European Political Community}

Another example of a failed political integration initiative in Western Europe followed the success of the ECSC initiative in 1952. After the outbreak of the Korean War in June 1950, the USA campaigned for West German rearmament to withstand a possible Soviet attack on Western Europe (Hughes, 1981:463). To prevent West Germany from abusing her reinstated military capabilities merely five years after the end of the Second World War, the French proposed a European Army for the common defence of Western Europe (Vaughan, 1976:56). 
This would have facilitated West German rearmament under supra-national European control. On 27 May 1952, a treaty setting up the European Defence Community (EDC) was signed in Paris (Van de Meerssche, 1971:135).

The existence of a European Army without a European political control mechanism contained potential problems. As the same six countries were members of both the ECSC and the EDC, a proposal was accepted for the integration of the ECSC and EDC into a European Political Community (EPC) (Van de Meerssche, 1971:138). However, due to a number of national and international reasons (Steyn, 1994:28-30) the EDC Treaty was never ratified by the national parliaments of the contracting countries. The EDC and EPC initiatives at political integration in Westem Europe thus both failed, while the ECSC's attempt at economic integration survived.

This experience illustrated the failure of political integration to keep up with the pace set by the economic success of the ECSC.

\section{The Bad Godesberg Agreement}

During the latter part of 1960 the French President, Charles de Gaulle, launched a drive towards political integration of the EEC countries on the basis of a political confederation of EEC states. De Gaulle stressed that co-operation between countries could be accomplished on political, economic, cultural and even military levels through discussions between national governments. Specialist organizations like the ECSC or Euratom, were to assist national governments in planning and discussions, but these organizations were to stay subordinate to the governments (Van de Meerssche, 1971:205-206).

During February 1961 a summit of EEC leaders convened in Paris to discuss the formation of a political union. After a second round of negotiations in July 1961, a declaration (the Bad Godesberg agreement) was issued. This declaration called for the proposed political integration to take on definite form by means of a treaty on political union (Van de Meerssche, 1971:208-211).

Opposition to the Bad Godesberg agreement was voiced as the Netherlands proposed the UK's inclusion in the initiative. The UK, however, did not support political integration due to her convictions concerning national sovereignty. By April 1962 opposition to the Bad Godesberg agreement mounted. The finalization of a treaty on political union was impossible. Political integration therefore failed once again. 
De Gaulle's response to the failure of his integration initiative resulted in the blocking of UK membership of the EEC in 1963 and 1967 (Steyn, 1994:57 \& 67). It was not before 1972, after De Gaulle's departure from EC politics, that the UK, together with Denmark and Ireland, was able to join the Communities. Political sensitiveness therefore delayed a widening of EEC membership for at least ten years.

\section{The French boycott of EEC activities}

The French also boycotted EEC activities between July 1965 and January 1966. This was because De Gaulle perceived EEC common agricultural policy and institutional reforms as threatening to the national sovereignty of member states (Steyn, 1994:63).

Something perceived to be of political nature thus effectively suspended progress in economic integration for six months. Without a resolution of differences (which cost Walter Hallstein his position as chairman of the European Commission), the action could have terminated the existence of EEC integration as it was then known.

\section{The Single European Act (SEA) and Maastricht Treaty}

A final example in this regard is to be found in developments surrounding the SEA and the Maastricht Treaty. The Maastricht Treaty can be seen as a continuation of the SEA of 1985. The SEA revised institutional provisions of the three constituting treaties of the EC (i.e. the ECSC, EEC and Euratom Treaties) to facilitate EC political co-operation. The Mastricht Treaty carried these aspirations forward by inter alia relying on principles relating to the amendment of EC Treaties to allow for further institutional reform, the formulation of a Common Foreign and Security Policy (FSP), co-operation in the spheres of Justice and Home Affairs, an Economic and Monetary Union (EMU) and the introduction of concepts like economic and social cohesion and the establishment of European citizenship (Hunnings \& Hill, 1993:719-720).

It is too early to comment on the success of the Maastricht Treaty, but observations can be made about the difficulties experienced in ratifying the Treaty in order to implement its provisions. In the French referendum of September 1992 only a slight majority in avour of ratification of the Treaty was registered (Walsh, 
1992:22-23). Denmark required two referendums to pass a "yes" in favour of the Treaty (Zagorin, 1992:32-34).

It follows that integration progress was once again hampered by factors perceived to be of political nature. EMU may sound to be of economic relevance, but the accompanying political perception about the importance of national sovereignty relating to central bank independence, a national currency and monetary policy formulation is threatening smooth progress towards integration in this field.

\section{Evaluation}

EC political integration initiatives were in general not as successful as the economic ones. They mainly served to delay EC integration, rather than to promote it. This resulted from a variety of reasons. Structural clumsiness defeated the Council of Europe. Changing national and international political realities left the EDC and EPC stillborn. Convictions surrounding national sovereignity sunk the Bad Godesberg Agreement. Political wilfulness resulted in the French veto of UK membership as well as boycott of EEC activities. Reluctance to cede national symbols hampered ratification of the Maastricht Treaty.

\section{CONCLUSION}

This study defined the concept of economic integration and gave the EC (today EU) as an example thereof. The rationale for Western European (economic) integration following the Second World War was also discussed.

In an attempt to answer the two initial questions posed, a concise exposition of the economic success and political failure of EC integration was set out. Generally the conclusion can be drawn that integration initiatives structured along economic lines of activity were more successful than were the political ones. This results largely from the jealousy with which the vestiges of national sovereignty were guarded. The unfortunate error must, however, not be made to discard all political efforts towards integration. Successful economic integration will not be possible without the political will to achieve it.

Contemporary EC political will originated with the desire to avoid any future destruction like that caused by the Second World War. This is still prevalent today, flowing from the economic advantages successful integration has offered. 
Political influences have, however, to be tempered. Integration is not to become a goal in itself, but should complement economic initiatives aimed at realizing the related economic advantages.

\section{REFERENCES}

1. ANON. (1992) Treaty on European Union. White Paper. Dublin: Government Publications.

2. ANON. (1993) Delors Report Suggests Step-by-Step Process of European Integration, IMF Survey, 18(4):209-219.

3. ANON. (1994) Twelve for the price of one. Global Trade, 2(2):3. Pretoria: Department of Trade and Industry.

4. BALASSA, B. (1961) The Theory of Economic Integration, Homewood: Irwin.

5. COMMISSION OF EUROPEAN COMMUNITIES. (1985) Completing the Internal Market. White Paper from the Commission to the European Council, Luxembourg: Office for Official Publications of the European Communities.

6. FEATHERSTONE, K. (1990) The successful manager's guide to 1992. Working in the New Europe. Fontana: Collins.

7. GOODMAN, S.F. (1992) The European Community. Houndmills: Macmillan.

8. EUROPEAN COMMUNITIES. (1971) The Facts. Brussels: European Communities Press.

9. KERR, A.J.C. (1977) The common market and how it works. Oxford: Pergamon Press.

10. HUGHES, H.S. (1981) Contempory Europe: a history. New Yersey: Prentice Hall.

11. HUNNINGS, N.M. \& HILL, J.M. (1993) The Treaty of Rome consolidated and :ae Treaty of Maastricht. London: Sweet \& Maxwell.

12. LANE, P. (1985) Europe since 1945. An Introduction. London: Batsford Academic and Educational.

13. LICHTHEIM, G. (1963) The New Europe. Today and Tomorrow, New York: Praeger. 
14. MATTHEWS, J. (1987) International Economic Relations for South African Students, Johannesburg: Southern.

15. MAYER, D.G. (1990) The external implications of closer European integration. National Institute Economic Review, 134:73-85, Nov,

16. POLACH, J.G. (1964) Euratom. It's background, issues and economic implications. New York: Oceana.

17. ROBINSON, J. (1992) The European Challenge. 1992. The benefits of a Single Market. Aldershot: Wildwood House.

18. SEERS, D. (1982) The second enlargement in historical perspective. In Seers, D. \& Vaitsos, C. (eds). The second enlargement of the EEC. The integration of unequal partners. New York: St Martins Press: 1-21.

19. SMITH, K.W. (1985) The emergence of superpowers and the period of uneasy peace, 1945-1964. In Van Wyk, T. \& Boucher, M. (eds). Europe 1848-1980, Pretoria: Academica: 413-451.

20. STEYN, T.F.J. (1994) The development of economic integration in the European Communities (EC): 1945-1992, Potchefstroom.

21. SWANEPOEL, J. (1959) Europese Ekonomiese Samewerking sedert die Tweede Wêreldoorlog, Pretoria: University of South Africa.

22. TINBERGEN, J. (1954) International Economic Integration. Amsterdam: Elsevier.

23. VAN DE MEERSSCHE, P. (1971) De Europese Integratie: 1945-1970. Antwerpen: Standaard Wetenschaplijke Uitgeverij.

24. VAUGHAN, R. (1976) Post-War Integration in Europe, London: Edward Arnold.

25. WALSH, J. (1992) And now vox, populi. Time Magazine, 5/10/95:22-23.

26. WALSH, A.E. \& PAXTON, J. (1972) Into Europe. The Structure and Development of the Common Market. London: Hutchinson.

27. WEGS, J.R. (1984) Europe since 1945. A concise history. London: Macmillan.

28. ZAGORIN, A. 91992) A sea of troubles. Time Magazine, 15/6/92:32-34. 